\title{
Activation of Platelet-activating Factor (PAF) Receptor Stimulates Nitric Oxide (NO) Release Via Protein Kinase C- $\alpha$ in HEC-1B Human Endometrial Epithelial Cell Line
}

\author{
Sharon Dearn' ${ }^{1}$ Mabhub Rahman' ${ }^{1}$ Aurélia Lewis ${ }^{2}$, Zahra Ahmed ${ }^{1}$, \\ Margaret C. Eggo' ${ }^{2}$, and Asif Ahmed ${ }^{1}$ \\ ${ }^{1}$ Department of Reproductive and Vascular Biology, Division of Reproductive and \\ Child Health, Birmingham Women's Hospital, University of Birmingham, \\ Edgbaston, Birmingham, U.K. ${ }^{2}$ Division of Medicine, Queen Elizabeth Hospital, \\ Edgbaston, Birmingham, U.K.
}

Accepted November 25, 1999.

\begin{abstract}
Background: Impairment of the fertility in the platelet-activating factor (PAF) receptor transgenic female mice suggests changes in PAF functions can influence uterine receptivity. We hypothesized that vasodilatory actions of PAF in the uterus was exerted by PAF-mediated nitric oxide (NO) release via activation of isoenzyme-specific protein kinase C (PKC). Materials and methods: Inducible and endothelial NOS was shown by Reverse transcription polymerase chain reaction RT-PCR in cDNA synthesized from RNA extract of proliferative and secretory endometrium as well endometrial epithelial cell lines HEC-1B. The effect of WEB2 170, $\mathrm{N}^{\mathrm{G}}$-monomethyl-Larginine (L-NMMA) and Ro31-8220 on PAF mediated NO release by HEC-1B cell was determined. PAF induced translocation of PKC $\alpha$ in HEC-1B cell and its antagonist effect by Ro 31-8220 was studied by Western immunoblot analysis. PKC isoenzyme regulated by PAF was determined in HEC-1B cell lysate by immunoprecipitation.

Results: PAF-evoked a rapid and concentrationdependent biphasic increase in total NO in human HEC-1B endometrial epithelial cell line [as measured by a Sievers NOA 280A NO Chemiluminescent Analyser.] This increase in NO release was attenuated by the PAF receptor antagonist, WEB2 170 . Inhibition of NO synthesis by $\mathrm{N}^{\mathrm{G}}$-monomethylL-arginine produced marked dose-dependent atten-
\end{abstract}

uation of PAF-mediated NO release, indicating nitric oxide synthase (NOS) activation. PAF-mediated NO release was also inhibited by the PKC inhibitor Ro 31-8220 and by the removal of extracellular calcium, suggesting a dependency on PKC and calcium, respectively. RT-PCR analysis showed expression of inducible NOS and endothelial NOS in human endometrium, myometrium and HEC-1B cells. Western immunoblot analysis showed PKC $\alpha$, $\beta \mathrm{II}$ and $\iota$ were the principal isozymes present in the HEC-1B cell line and normal endometrium, suggesting that both HEC-1B cells and normal endometrium have similar PKC isozymes. PAF induced the translocation of both PKC $\alpha$ and PKC $\iota$ within the time frame of NO release. The translocation of $\mathrm{PKC} \alpha$, but not PKC $\iota$, was susceptible to inhibition by Ro 31-8220 that also inhibited PAFevoked NO release, suggesting that $\operatorname{PKC} \alpha$ is the principal isozyme involved in this process and that eNOS may be a substrate for PKC $\alpha$. Kinase assays performed using immunoprecipitated $\mathrm{PKC}^{\alpha}$ showed that PAF ( $1 \mathrm{nM}$ ) activated PKC $\alpha$ that was inhibited by co-incubation with Ro31-8220 and $\mathrm{Ca}^{2+}$-free medium.

Conclusions: This study demonstrates that PAFstimulated NO release via $\mathrm{PKC}^{\alpha}$ in epithelial cells might regulate endometrial functions such as implantation and menstruation.
Address correspondence and reprint requests to: Professor Asif S. Ahmed, Department of Reproductive and Vascular Biology, Division of Reproductive and Child Health, University of Birmingham, Birmingham Women's Hospital, Edgbaston, Birmingham, B15 2TG, U. K. Phone: $44+021$ 627 2705; Fax: 44 + 021414 1576; E-mail:

A.S.Ahmed@bham.ac.uk

\section{Introduction}

Platelet-activating factor (PAF) is a potent, inflammatory lipid mediator that increases vascular permeability and vasodilatation processes that accompany human implantation and men- 
struation $(1,2)$. The potent vasodilatory and vascular permeability properties of PAF may relate to its ability to stimulate the release of agents such as nitric oxide (NO) (3), a labile intracellular messenger molecule which modulates blood vessel tone via activation of smooth muscle cytosolic guanylate cyclase (4). Furthermore, inhibition of endogenous NO synthesis can promote leakage of fluid and protein from capillaries (5), suggesting an important role for NO in regulating vascular permeability, a process closely associated with implantation (6). Formation of NO is achieved by the conversion of $\mathrm{L}$-arginine to $\mathrm{L}$-citrulline by the enzyme NO synthase (NOS) in the presence of molecular oxygen, NADPH and cofactors consisting of tetrahydrobiopterin, heme, flavin adenine dinucleotide and flavin mononucleotide (7). Three main isoforms of NOS are neuronal (8), endothelial (9) and inducible NOS (10), displaying about $50 \%$ amino acid sequence homology. The two constitutively expressed NOS isoforms identified in endothelium and cerebellum are $\mathrm{Ca}^{2+}$-dependent and calmodulin-dependent and they synthesize small amounts of NO upon activation. The third inducible NOS is $\mathrm{Ca}^{2+}$-independent, although it binds calmodulin and is mainly seen in macrophages and neutrophils (11).

A recent study demonstrated the expression of endothelial NOS mRNA in the endometrial glandular epithelium, endometrial stroma and the myometrial blood vessels (12). Despite this and the suggestive importance of NO in implantation and menstruation $(13,14)$, its production and regulation in human endometrium have not been described. Agonists that release endothelial NO share the ability to stimulate phospholipase C. PAF is known to stimulate phospholipase $\mathrm{C}$ from both normal endometrial tissue (15) and from endometrial epithelial cell line, HEC-1B cells (16). This activation generates two distinct second messengers: inositol $(1,4,5)$-trisphosphate and $s n$-1,2 diacylglycerol, which activates protein kinase C (PKC). The endothelial NOS cDNA contains consensus sequences for phosphorylation by protein kinases including PKC and cyclic AMP-dependent protein kinase. NOS phosphorylation by PKC reduces NOS catalytic activity in the brain (17) and vascular endothelium (18), however in epithelial cells its actions are unknown.

PKC is not a single entity, but a family comprising at least 12 isozymes, which differ in their subcellular distribution, activation requirements and tissue expression $(19,20)$. This suggests that each of the isozymes could have discrete functions in cell signaling. PKC isozymes activated following phospholipase activation can vary, offering a means to regulate cellular function via a common signalling pathway. PKC isozymes $\alpha, \beta$ and $\gamma$ are $\mathrm{Ca}^{2+}$-dependent; whereas, PKC isozymes $\delta, \epsilon, \zeta, \eta, \theta$ are $\mathrm{Ca}^{2+}$-independent. All of these isozymes, with the exception of $\mu, \lambda$ and $\zeta$, are activated by phorbol ester, diacylglycerol and free fatty acids (20). Here we hypothesize that the vasodilatory effect of PAF may relate to its ability to stimulate the release of NO via PKC. The aim of this study was, therefore, to investigate the effect of PAF on the regulatory mechanisms involved in NO biosynthesis in HEC-1B cells, as this cell line was shown previously to possess functional PAF receptors and to retain many of the characteristics of endometrial epithelial cells (16).

\section{Materials and Methods}

\section{Identification of the NOS Isozymes in the HEC-1B Cell Line}

Normal endometrial tissue was obtained from women undergoing sterilization. Ethical approval was obtained from the South Birmingham Ethical Committee. Total RNA was extracted from proliferative and secretory endometrium as well as from monolayers of HEC-1B endometrial epithelial adenocarcinoma cells (American Type Culture Collection, Rockville, $\mathrm{MD}$ ) by a single-step procedure based on the method of Chomczynski and Sacchi (21). Briefly, endometrial tissue was homogenized in RNAzol ${ }^{\mathrm{TM}} \mathrm{B}$ (AMS Biotechnology (Europe) Ltd., Oxon, U.K.) while cell monolayers were lysed directly in the tissue culture flask and total RNA purified by acidphenol extraction and ethanol precipitation. cDNA was synthesized from total RNA using the Superscript ${ }^{\mathrm{TM}}$ Preamplification System for first strand cDNA synthesis (GibcoBRL Life Technologies, Paisley, Scotland). Briefly, $10 \mu \mathrm{g}$ of total RNA was primed with $0.5 \mu \mathrm{g} / \mu \mathrm{l}$ oligo $(\mathrm{dT})_{12-18}$ and reverse transcribed in a total volume of $20 \mu \mathrm{l}$ of reaction mixture consisting of $10 \mathrm{mM}$ of all four dNTP's, $25 \mathrm{mM} \mathrm{MgCl} 2,0.1$ M DTT and 200 units/ $\mu$ l of Superscript II RT in a buffer containing $200 \mathrm{mM}$ tris- $\mathrm{HCl}(\mathrm{pH} \mathrm{8.4})$ and $500 \mathrm{mM} \mathrm{KCl}$, according to the manufacturer's instructions. For amplification by PCR, $2 \mu \mathrm{l}$ of RT product was amplified with 2.5 units 
Taq DNA polymerase and $10 \mu \mathrm{M}$ of sense and antisense NOS primers in $50 \mu \mathrm{l}$ of reaction mix containing $500 \mathrm{mM} \mathrm{KCl}, 200 \mathrm{mM}$ tris- $\mathrm{HCl}$ and $\mathrm{MgCl}_{2}$ [human inducible NOS (iNOS): $1.75 \mathrm{M}$; human constitutive endothelial NOS (eNOS): $1.5 \mathrm{M}$ ] for 35 cycles as follows: iNOS: $95^{\circ} \mathrm{C}, 30$ sec; $55^{\circ} \mathrm{C}, 30 \mathrm{sec} ; 72^{\circ} \mathrm{C}, 60 \mathrm{sec}$; eNOS: $95^{\circ} \mathrm{C}, 30$ sec; $60^{\circ} \mathrm{C}, 30 \mathrm{sec} ; 72^{\circ} \mathrm{C}$, $60 \mathrm{sec}$ Products were then analyzed by agarose gel electrophoresis. The sense primers for iNOS were 5'GAATCTTGGAGCGAGTTGTGG-3' (nucleotide number: 2368-2350) and antisense were 5'CCAGCTTCTTCAAAGTGGTAG-3' (nucleotide number: $3286-3266)$. The sense primers eNOS were 5'-CCCCCCGAGCTCCCCGCTAAC-3' (nucleotide number: 135-155) and anti-sense were 5'-GCAGTCCCGGGCATCGAACAC-3' (nucleotide number: 629-649). The PCR products were subcloned and sequenced to confirm their identity.

\section{Preparation and Stimulation of Cells}

HEC-1B cells were maintained in $80 \mathrm{~cm}^{2}$ flasks in Dulbecco's modified Eagle's medium (DMEM) containing $10 \%(\mathrm{v} / \mathrm{v})$ fetal calf serum, $1 \%$ l-glutamine, $100 \mathrm{U} / \mathrm{ml}$ penicillin and 100 $\mu \mathrm{g} / \mathrm{ml}$ streptomycin at $37^{\circ} \mathrm{C}$, in $95 \%$ air and $5 \% \mathrm{CO} 2$ in a humid atmosphere. Subconfluent monolayers were plated at a density of 300,000 cells $\mathrm{ml}$ in 24-well culture plates and grown in complete culture media for 24-36 hr. Before agonist stimulation, growth medium was removed from near confluent monolayers and cells were serum-starved for $24 \mathrm{hr}$. Cells were stimulated by the addition of PAF-acether alone (C18-PAF, Sigma Chemical Co. Ltd., Poole, U.K.) in DMEM containing $0.2 \%$ bovine serum albumen (BSA; Sigma Chemical Company Ltd.) or in the presence of either WEB 2170 (PAF receptor antagonist) or $\mathrm{N}^{\mathrm{G}}$ monomethyl-L-arginine (L-NMMA; nitric oxide synthesis inhibitor; Sigma).

\section{Measurement of Nitric Oxide}

For concentration-dependence and time-course experiments, stimulations were initiated, for the times indicated, in a final volume of $0.5 \mathrm{ml}$ at $37^{\circ} \mathrm{C}$. For experiments with low $\mathrm{Ca}^{2+}(150$ nM) Hank's buffered saline and PKC inhibitor Ro 31-8220, cells were pretreated for $30 \mathrm{~min}$ and stimulations were then initiated in a final volume of $0.5 \mathrm{ml}$ at $37^{\circ} \mathrm{C}$ for a further $30 \mathrm{~min}$. Reactions were terminated by removal of the supernatant that was subsequently stored at $-70^{\circ} \mathrm{C}$ for NO analysis. Levels of NO were measured in the gas phase using a Sievers NOA 280A chemiluminescence analyzer as previously described (22). Samples of cell culture medium $(100 \mu \mathrm{l})$ were injected into a nitrogen purge vessel containing a $1 \%$ solution of sodium iodide in glacial acetic acid to liberate gaseous NO from dissolved NO and nitrite. The sample gas was then exposed to ozone in the reaction vessel to form activated nitrogen dioxide $\left(\mathrm{NO}^{*}\right)$, which was detected by a redsensitive photomultiplier tube and the output recorded using an integrating pen recorder. For each sample, the area under the curve was converted to pmol NO using a calibration curve constructed following the analysis of a series of sodium nitrite standards.

\section{Preparation of Cell Lysates}

Cultured HEC-1B cells were maintained in 25 $\mathrm{cm}^{2}$ flasks in DMEM containing $10 \%(\mathrm{v} / \mathrm{v}) \mathrm{fe}-$ tal calf serum (FCS), 1\% L-glutamine, 100 $\mathrm{U} / \mathrm{ml}$ penicillin and $100 \mu \mathrm{g} / \mathrm{ml}$ streptomycin) at $37^{\circ} \mathrm{C}$, in $95 \% \mathrm{O} 2$ and $5 \% \mathrm{CO}_{2}$, in a humid atmosphere. For protein extraction, growth medium was removed and subconfluent $(85 \%)$ monolayers washed with ice-cold PBS prior to the addition of $250 \mu \mathrm{l}$ of lysis buffer. The buffer contained $50 \mathrm{mM}$ Tris- $\mathrm{HCl}, \mathrm{pH} 7.8,1 \%$ Triton $\mathrm{X}-100,0.1 \%$ SDS, $250 \mathrm{mM} \mathrm{NaCl}, 5 \mathrm{mM}$ EDTA, $1 \mathrm{mM}$ PMSF, $1 \mu \mathrm{g} / \mathrm{ml}$ aprotinin, leupeptin and pepstatin. Flasks were then shaken on an orbital shaker for 10 minutes at $4{ }^{\circ} \mathrm{C}$ before transfer to prefrozen eppendorfs. Following centrifugation $\left(13,000 \mathrm{rpm}, 4^{\circ} \mathrm{C}, 10 \mathrm{~min}\right)$, the protein concentration of the supernatant was determined using the Bio-Rad protein assay (Bio-Rad Laboratories Ltd., Hertfordshire, U.K.) with BSA as standard.

\section{Western Immunoblot Analysis}

The non-radioactive ECL Western Blotting System was used to determine the PKC isozymes present in endometrial epithelial cell lysates. Briefly, $20 \mu \mathrm{g}$ total protein was diluted to $20 \mu \mathrm{l}$ with sample buffer $(0.02 \mathrm{M}$ tris- $\mathrm{HCl}, 0.002 \mathrm{M}$ EDTA, $2 \%$ SDS, $10 \% 2$ mercaptoethanol, $20 \%$ glycerol and $0.002 \%$ bromophenol blue) and electrophoresed in a $10 \%$ SDS-polyacrylamide minigel at $50 \mathrm{~V}$ for approximately $2 \mathrm{hr}$. After electrophoresis, proteins were transferred onto a nitrocellulose 
membrane in a cooling system $\left(10^{\circ} \mathrm{C}\right)$ for $3 \mathrm{hr}$ at $50 \mathrm{~V}$. The filter was blocked to reduce nonspecific binding using tris-buffered-salinetween (TBS-T) containing 5\% skimmed milk and $0.1 \%$ BSA for $4 \mathrm{hr}$ at room temperature. After washing in TBS-T $(3 \times 20$ minutes $)$, the membrane was incubated overnight at $4^{\circ} \mathrm{C}$ with affinity purified antibodies specific to various members of the PKC family (PKCs $\alpha$, $\beta \mathrm{I}$ and $\beta \mathrm{II}, \delta, \epsilon, \eta, \iota$ and $\zeta$; Binding site, Birmingham, U.K.) and diluted 1:500. The amino acid sequences against which these antibodies were raised are specific for each isozyme. The amino acid sequences against which the three key antibodies used in this study are given below:

anti-PKC-iota antibody: PSSHESLDQVGEEKEAMNTRESGK (between amino acids 212 and 235).

a anti-PKC-zeta antibody: EETDGIAYISSSRKHDSIKDDSED (between amino acids 199 and 222).

anti-PKC-alpha antibody: PSEDRKQPSNNLDRV (between amino acids 320-334).

Filters were washed and incubated with the secondary peroxidase-labeled anti-sheep antibody diluted 1:10,000 for $2 \mathrm{hr}$ at room temperature. After a final wash in TBS-T, filters were incubated for $1 \mathrm{~min}$ at room temperature in detection reagent, immediately wrapped in saran wrap and exposed to X-ray film. A single band of the molecular weight of the full-length isozyme was found for PKCs $\alpha, \beta 11, \epsilon$ and $\iota$. For other PKC isozymes, the staining of the full-length PKC isozymes was weak and indistinguishable from nonspecific staining.

\section{Cell Treatment and Subcellular Fractionation}

HEC-1B cells were maintained in $25 \mathrm{~cm}^{2}$ flasks as previously described. Before agonist stimulation, growth medium was removed and near confluent monolayers serum-starved for $24 \mathrm{hr}$. Stimulations were initiated by the addition of $1 \mathrm{nM}$ PAF in DMEM without fetal calf serum and cultures treated for the times indicated. After removal of the medium, cells were rinsed with ice-cold PBS and then scraped into $250 \mu \mathrm{l}$ of sonication buffer $(0.25 \mathrm{M}$ sucrose, $10 \mathrm{mM}$ DTT, $2 \mathrm{mM} \mu \mathrm{g} / \mathrm{ml}$ leupeptin). Cells were then sonicated (Soniprobe, setting 5) for $3 \times 10 \mathrm{sec}$ and the soluble and particulate fractions separated by centrifugation at $100,000 \times \mathrm{g}$ for 30 min (Beckman TLA 120.1 fixed angle rotor, Beckman Instruments UK Ltd., Buckinghamshire, U.K.). The supernatants were collected, and the membrane pellets were suspended in $150 \mu \mathrm{l}$ of sonication buffer, sonicated for $3 \times 10$ sec, incubated for $30 \mathrm{~min}$, and then centrifuged at $100,000 \times \mathrm{g}$ for $30 \mathrm{~min}$. The resulting supernatants were designated membrane fractions. The protein concentrations of cytosolic and membrane fractions were determined and Western immunoblot analysis performed as previously described.

\section{Protein Kinase C $\alpha$ Assay}

Cells were incubated for $24 \mathrm{hr}$ in medium without serum. Ro31-8220 was added 30 min prior PAF ( 1 to $10 \mathrm{nM}$ ) and incubation was continued for another $60 \mathrm{~min}$. Medium was removed and the method of Monks et al. (23) for preparing cell lysates was followed. Cell lysates (100 $\mu \mathrm{l})$ were incubated overnight at $4^{\circ} \mathrm{C}$ with $0.2 \mu \mathrm{g}$ immunoglobulin G (IgG) to PKC ${ }^{\alpha}$. Immunoprecipitates were incubated with Protein G (formalin fixed; volume added according to the manufacturer instructions) for $2 \mathrm{hr}$ on ice and washed $3 \times$ with PKC kinase buffer without $\beta$-glycerophosphate. The kinase reaction was performed as described, but $3.5 \mu \mathrm{g}$ histone $\mathrm{Hl}$ was used and $\left[\gamma^{33} \mathrm{P}\right] \mathrm{ATP}(2 \mu \mathrm{Ci} /$ assay $)$ was substituted for $\left[\gamma^{32} \mathrm{P}\right]$ ATP. The reaction was stopped by adding reducing sample buffer $(2 \times)$ and samples were boiled for $10 \mathrm{~min}$. Samples were run on a $10 \%$ SDS-PAG gel and proteins were transferred to a PVDF membrane (Amersham Pharmacia, Buckinghamshire, U.K.).

${ }^{33} \mathrm{P}$-labeled proteins were determined by autoradiography.

\section{Statistical Analysis}

All data are expressed as mean \pm S.E.M. Statistical analysis was performed using Student's dependent (unpaired) and dependent (paired) t-test. These tests were performed on log normalized data.

\section{Results}

Amplification of cDNA from HEC-1B cells by RT-PCR using primers directed against the inducible and the endothelial NOS isozymes, produced a single band for each of the predicted size (Fig. IA and B). Sequencing con- 


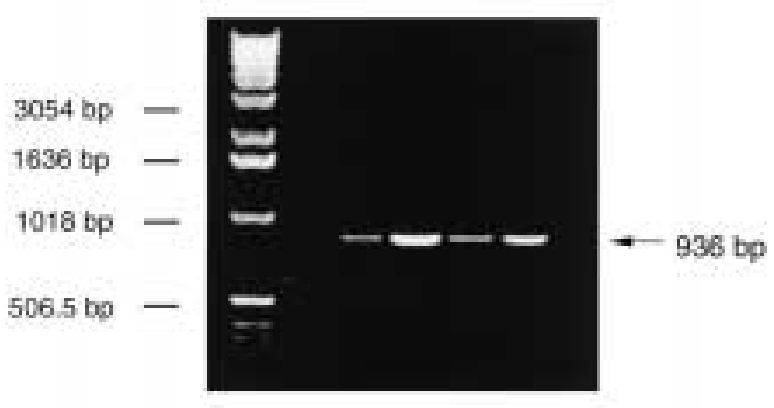

(B)

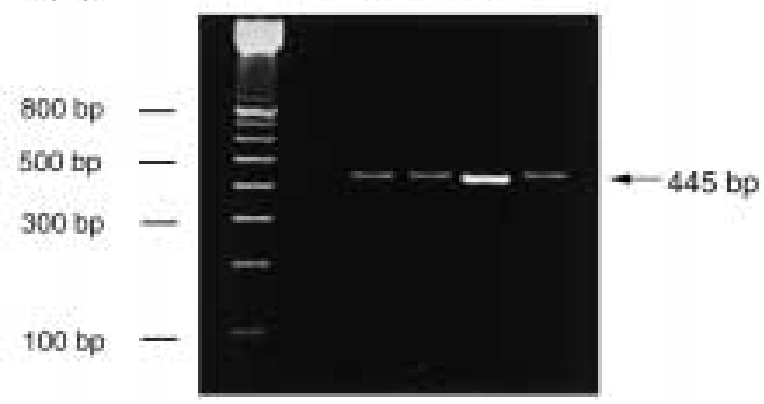

Fig. 1. Reverse transcription polymerase chain reaction (RT-PCR) for the inducible $(A)$ and constitutive endothelial (B) NOS isoforms. Samples of total RNA from human HEC-1B cells (lane 2 ), proliferative (lane 3 ), secretory (lane 4) endometrium, macrophages (lane 5 in A) or human pregnant labouring myometrium (lane 5 in $\mathrm{B}$ ). Control reactions with no input cDNA (lane 1) were subjected to RT-PCR using primers specific for both NOS isoforms. A single band of $936 \mathrm{bp}$ for iNOS can been seen in panel $A$ and of $445 \mathrm{bp}$ for eNOS in panel B.

firmed these to be inducible and endothelial NOS, respectively.

Consistent with activation of a constitutive NOS, NO formation increased rapidly in response to $1 \mathrm{nM}$ PAF, exceeding basal release by $5.6 \% \pm 0.65 \%$ within $30 \mathrm{sec}$, the earliest time point measured ( $p<0.01, n=4$; Fig. 2 ) and reaching a maximum within $10 \mathrm{~min}$ of stimulation. Thereafter, total NO levels reached a plateau, but remained elevated. Addition of PAF receptor antagonist WEB2 170 after $15 \mathrm{~min}$ of PAF stimulation inhibited PAF-evoked NO release in a time-dependent manner (Fig. 2) indicating that PAF-mediated NO release appears to be sustained over the time period studied. The increase in total NO evoked by PAF within the concentration range tested (1 pM to $1 \mu \mathrm{M}$ ) was completely blocked by addi-

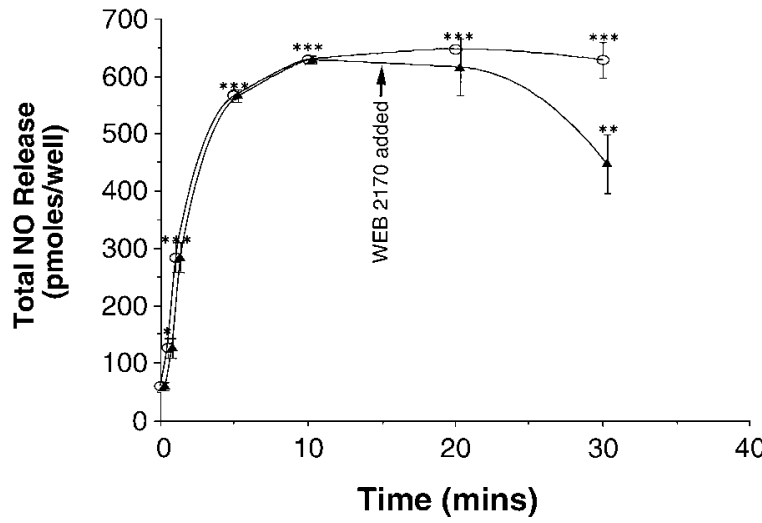

Fig. 2. Time course of platelet-activating factor (PAF) mediated nitric oxide (NO) release. Cells were stimulated with $1 \mathrm{nM}$ platelet-activating factor for the times indicated in the absence of WEB2 170 (open circle) or in the presence of $10 \mu \mathrm{M}$ WEB2 170 added after 15 min of stimulation (solid triangle). The results are expressed as means \pm S.E.M. of a typical experiment (triplicate determinations per experiment; 4 similar experiments). Statistical analysis was performed using Student's unpaired t test. ${ }^{*} p<0.01$ and ${ }^{* * *} p<0.0001$ when compared with basal values of total NO.

${ }^{* *} p<0.001$ when compared with the 30 min timepoint when WEB2 170 treatment was initiated. After $30 \mathrm{~min}$, basal NO release was $1535 \mathrm{pmol} /$ well and release in the presence of WEB2 170 alone was $1595 \mathrm{pmol} / \mathrm{well}$. These values have been subtracted from the test data.

tion of WEB $2170(10 \mu \mathrm{M})$ at the time of stimulation in all instances, except that which evoked maximal NO release (Fig. 3) indicating a PAR receptor-mediated response. Moreover, NO release appeared to be biphasic and that may reflect the involvement of two different receptor subtypes (Fig. 3). PAF receptor activation involves NOS activation, as indicated by the marked dose-dependent attenuation of PAF-evoked NO release by the NOS inhibitor $\mathrm{N}^{\mathrm{G}}$-monomethyl-L-arginine (L-NMMA; $1 \mathrm{nM}$ to $1 \mathrm{mM}$ ), with half-maximal inhibition $\left(\mathrm{IC}_{50}\right)$ at approximately $1 \mu \mathrm{M}$ (Fig. 4A).

The role of external $\mathrm{Ca}^{2+}$ and PKC were determined by conducting experiments in the presence of both low $\mathrm{Ca}^{2+}$ buffer and Ro 318220, a selective PKC inhibitor to identify the regulatory mechanisms involved in PAF-stimulated NO release. In the experiment shown in Figure 4B, the PAF-evoked NO release is PKC-dependent as Ro 31-8220 attenuated this response. Pretreatment of HEC-1B cells with $1 \mu \mathrm{M}$ Ro 31-8220 inhibited PAF-mediated NO release by $80 \%$ (Fig. 4B). In the presence of ex- 


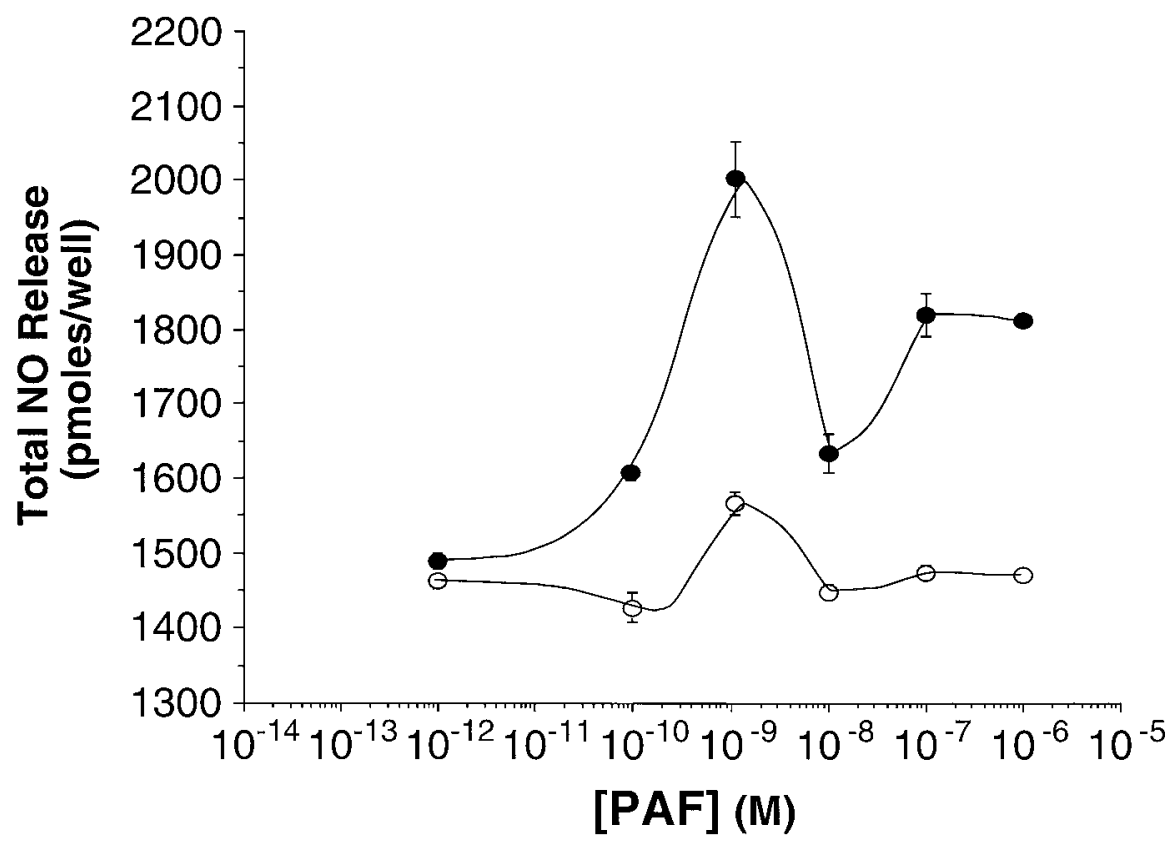

Fig. 3. Dose-dependent release of nitric oxide (NO) from human HEC-1B cells. HEC-1B cells were plated at a density of 300,000 cells $/ \mathrm{ml}$ in 24 well plates and grown to $80 \%$ confluency in Dulbecco's modified Eagle's medium (DMEM) containing $10 \%$ fetal calf serum. Following serum starvation, near confluent monolayers were stimulated for 30 min with an increasing concentration of platelet-activating factor (PAF, solid circle) or an

ternal $\mathrm{Ca}^{2+}, 1 \mathrm{nM}$ PAF evoked a significant increase in total NO release. In contrast, when stimulations were conducted in the presence of low $\mathrm{Ca}^{2+}$ buffer (150 nM), PAF-mediated NO release was significantly inhibited. Compared with control incubation performed in the same low $\mathrm{Ca}^{2+}$ buffer, PAF stimulated NO was just $19.3 \% \pm 1.68 \%$ above control, suggesting a dependency on extracellular $\mathrm{Ca}^{2+}(p<0.0001$, $n=9)$.

To identify the PKC isozymes involved in PAF-stimulated NO release, the PKC isozyme profile of the HEC-1B cell line was determined and the isozymes translocated in response to PAF stimulation within the time frame of NO production were identified. Western immunoblot analysis of whole cell extracts established that the HEC-1B cell line contained all but one of the eight PKC isozymes tested. PKC $\alpha, \beta \mathrm{II}, \epsilon$ and $\iota$ were identified as the major isozymes present (data not shown). PKC $\beta \mathrm{I}, \delta$ and $\eta$ were weakly positive. In contrast, PKC $\zeta$ was not present in detectable amounts.

All of the PKC isozymes were located pre- increasing concentration of platelet-activating factor in the presence of $10 \mu \mathrm{M}$ WEB2 170 (open circle). The media was removed and NO levels determined using a Sievers NOA 270B chemiluminescent analyser. The results are expressed as means \pm S.E.M. of a typical experiment (triplicate determinations per experiment; 3 similar experiments). Basal NO release was $1482 \mathrm{pmol} /$ well and has not been subtracted from the data.

dominantly in the cytosolic fraction of unstimulated cells, as shown for PKC $\alpha$ and PKC $\iota$ in Fig. 6 and Fig. 7, respectively. Treatment of cells with $1 \mathrm{nM}$ PAF induced a rapid translocation of $\operatorname{PKC} \alpha$, as detected by Western immunoblot analysis. Analysis of membrane fractions with a PKC $\alpha$-specific antibody showed that this isozyme associated with the membrane 1 min after PAF addition where it remained, to approximately the same extent, following 2, 5, 10 and 20 min of stimulation (Fig. 5A). This translocation was completely abolished by pre-treatment and stimulation in the presence of the PKC inhibitor, Ro 31-8220 (Fig. 5B). PKC $\iota$ was similarly located predominantly in the cytosol of resting confluent HEC-1B cells (Fig. 6). Analysis of membrane fractions with a PKC $\iota$-specific antibody showed that this isozyme associated with the membrane $30 \mathrm{sec}$ after PAF addition, with levels increasing progressively over the next $10 \mathrm{~min}$ of stimulation, only to return to the levels observed within 1 min of stimulation by 20 min (Fig. 6A). In contrast to the translocation observed with $\operatorname{PKC} \alpha$, 
A

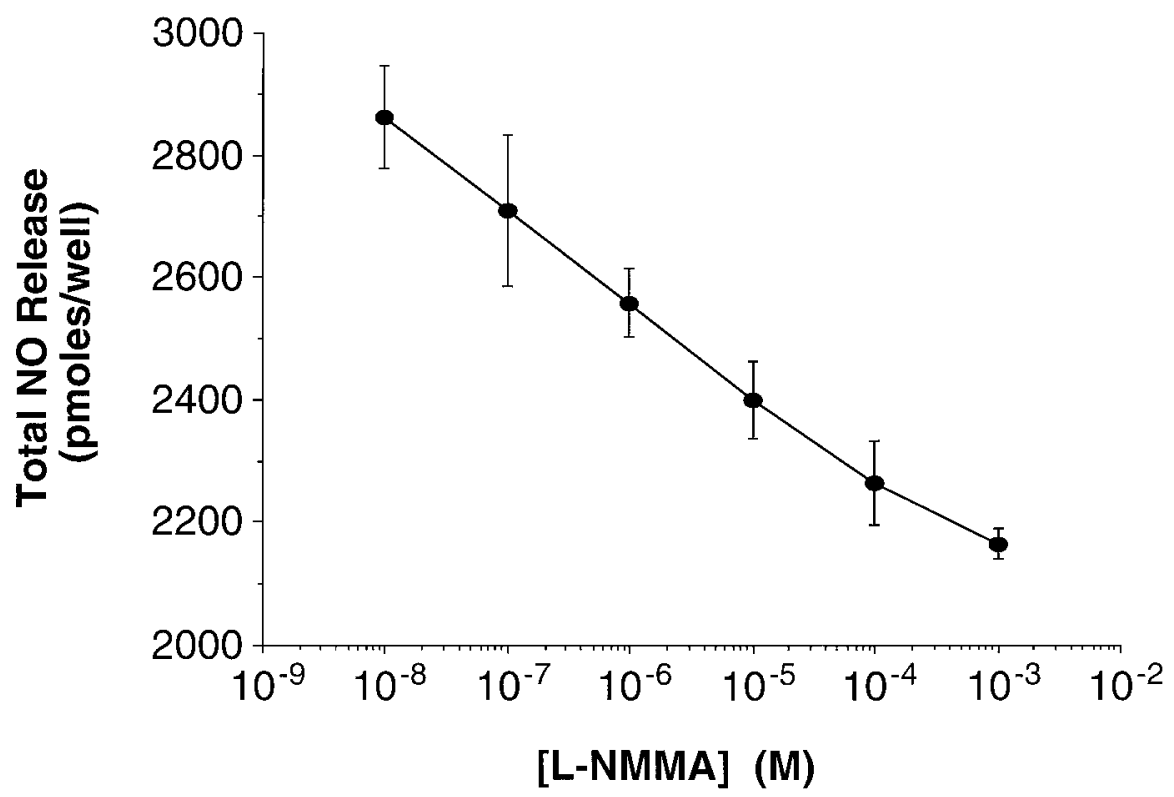

B

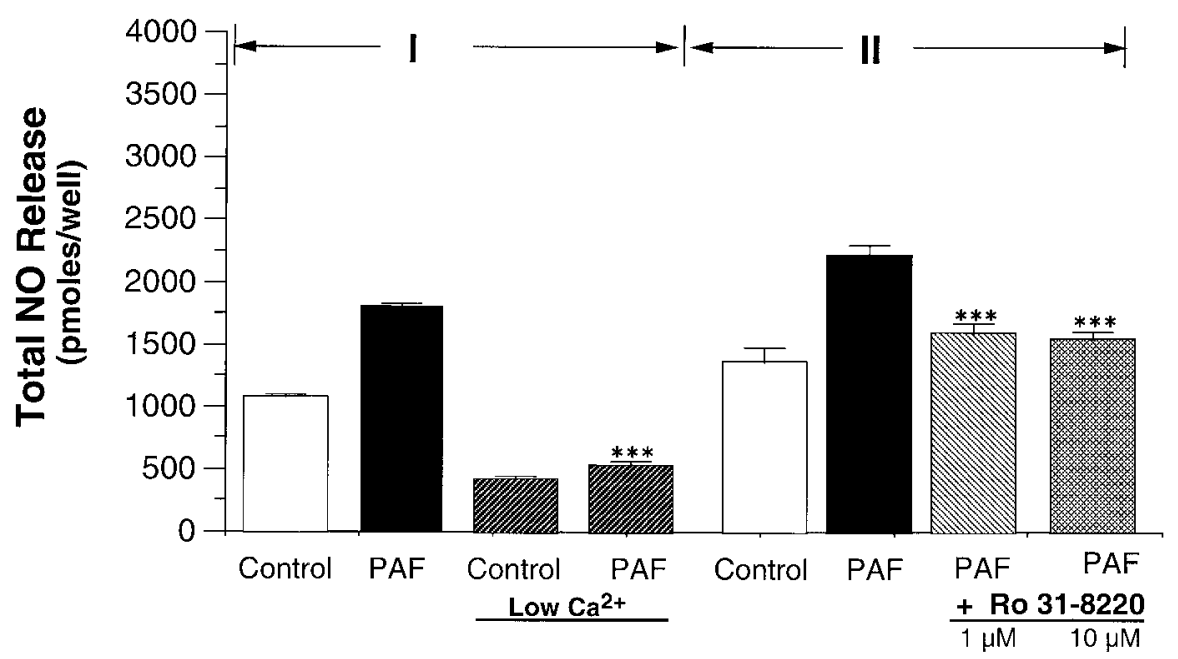

Fig. 4. Antagonistic effect of $\mathbf{N}^{\mathrm{G}}$-monomethylL-arginine (L-NMMA), low $\mathrm{Ca}^{2+}$ and Ro31-8220 on PAF mediated NO release by HEC-1B cell due to activation of NOS and PKC. (A) Effect of inhibition of NO synthesis by L-NMMA on PAFmediated NO release. HEC-1B cells were stimulated for $30 \mathrm{~min}$ with $1 \mathrm{nM}$ platelet-activating factor in the presence of increasing concentrations of $\mathrm{N}^{\mathrm{G}}$-monomethyl-L-arginine. The media was removed and NO levels determined using a Sievers NOA 270B chemiluminescent analyser. The results are expressed as means \pm S.E.M. of a typical experiment (triplicate determinations per experiment; 3 similar experiments). Basal NO release was 2150 pmol/well and PAF-mediated NO release in the absence of L-NMMA was $2995 \mathrm{pmol} / \mathrm{well}$. These values have not subtracted from the data. (B) Effect of inhibition of protein kinase $\mathrm{C}$ and low external $\mathrm{Ca}^{2+}$ and on PAF-mediated NO release from HEC1B cells. Following serum starvation, confluent monolayers were washed with sterile PBS and pretreated at $37^{\circ} \mathrm{C}$ with low $\mathrm{Ca}^{2+}$ buffer (150 nM external $\mathrm{Ca}^{2+}$ ) or with Ro 31-8220 at $1 \mu \mathrm{M} 30 \mathrm{~min}$. Cells were then stimulated with 1 nM PAF in standard media, in the presence of low $\mathrm{Ca}^{2+}$, in the presence of $1 \mu \mathrm{M}$ Ro 31-8220 for $30 \mathrm{~min}$. The results are expressed as means \pm SEM of a representative experiment ( $n=9 ; 2$ similar experiments). 
(A)
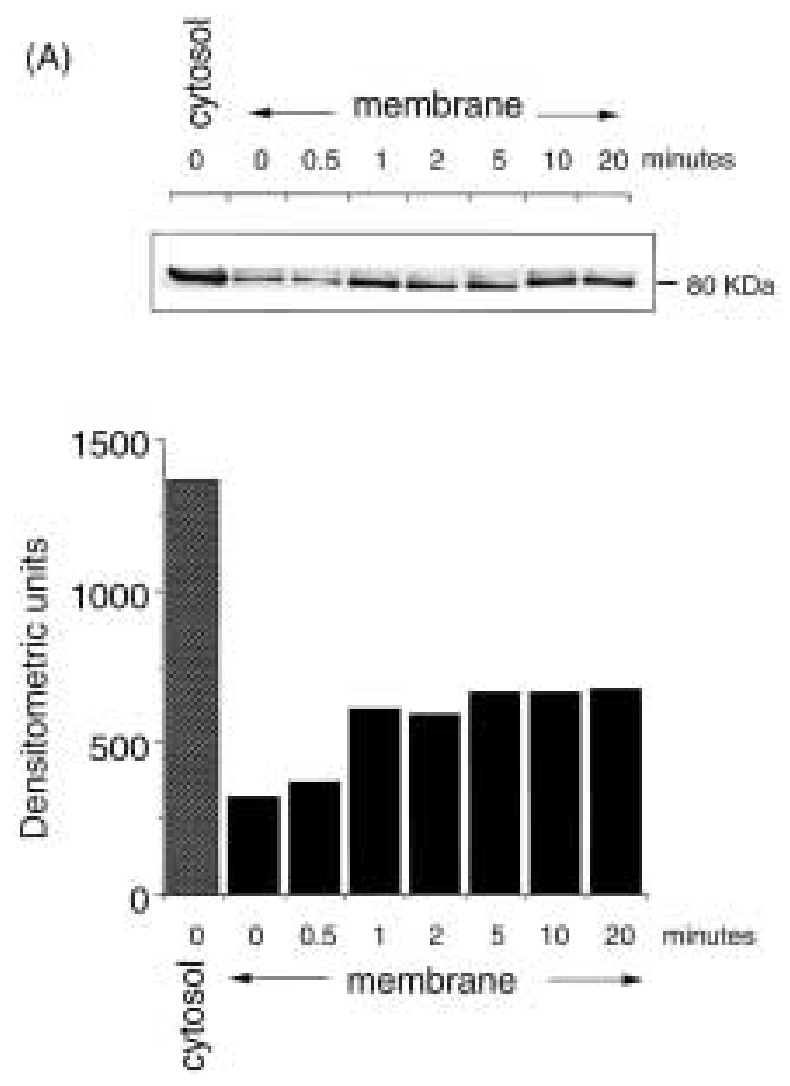

Fig. 5. Translocation of PKC $\alpha$ induced by PAF and its inhibition by Ro 31-8220. HEC-1B cells were incubated in the absence of serum for $24 \mathrm{hr}$ prior to stimulation with $1 \mathrm{nM}$ PAF either alone (A) or in the presence of the PKC inhibitor, Ro 318220 (B) for the times indicated. Cells incubated with PAF in the presence of $10 \mu \mathrm{M}$ Ro 31-8220 were pretreated for 30 minutes prior to stimulation. Cytosolic and particulate fractions were prepared

however, translocation of PKC $\iota$ was unaffected by pre-treatment and stimulation in the presence of the PKC inhibitor, Ro 31-8220 (Fig. $6 \mathrm{~B})$. No change in the cellular localization of all other PKC isozymes tested was observed in response to PAF stimulation

Activation of PKC $\alpha$ in response to PAF was determined in kinase assays shown in figure 7A. PAF ( $1 \mathrm{nM}$ ) produced pronounced activation of PKC $\alpha$ after lhr incubation. This effect was diminished at $10 \mathrm{nM}$ PAF. This pattern mimics the high activity seen with InM PAF in NO assays and the decrease seen at $10 \mathrm{nM}$ PAF (Fig. 3). The PKC inhibitor Ro31-8220 completely blocked activation by $1 \mathrm{nM}$ PAF. Studies in $\mathrm{Ca}^{2+}$-free Hank's balanced salt solution showed that PAF (1 nM) was unable to activate PKC $\alpha$ (Fig. 7B). Similarly PAF did not activate PKC $\alpha$ when cells
(B)
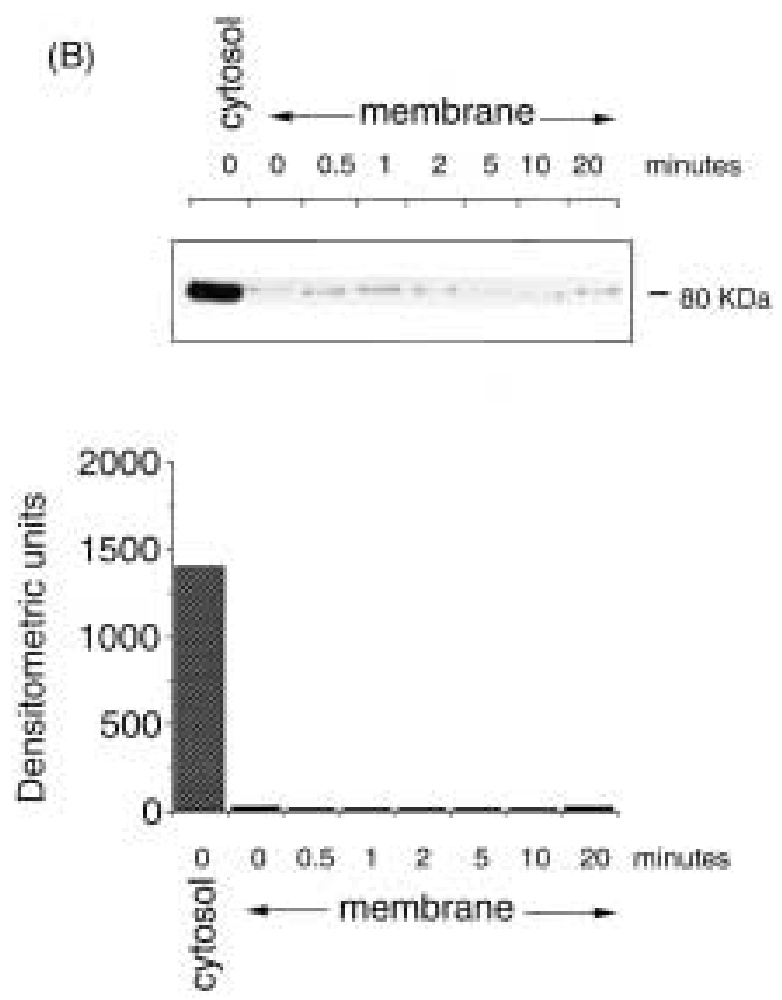

and analyzed by Western immunoblot analysis with PKC alpha antibody. Top panel: Western blot shows the location of the alpha isozyme in resting confluent cells, its association with the membrane following PAF addition (A), and inhibition of this association in the presence of Ro 31-8220 (B). Bottom panels of (A) and (B): Corresponding densitometric analysis. Presented are the results of a typical experiment $(n=4)$.

were cultured in medium containing $1 \mathrm{~m} M$ EGTA. In fact, in both $\mathrm{Ca}^{2+}$-free salt solution and in EGTA-supplemented medium, PKC $\alpha$ kinase activity was higher in the control incubations than the PAF-stimulated samples.

\section{Discussion}

This is the first study to conclusively demonstrate that activation of PAF receptor stimulates the release of NO from a human endometrial epithelial cell line and that this response is dependent on PKC $\alpha$ activation. The release of NO was rapid and $\mathrm{Ca}^{2+}$-dependent, consistent with activation of a constitutive isoform of NOS (24). The presence of mRNA encoding constitutive endothelial NOS was demonstrated by RT-PCR and is in agreement with 
(A)
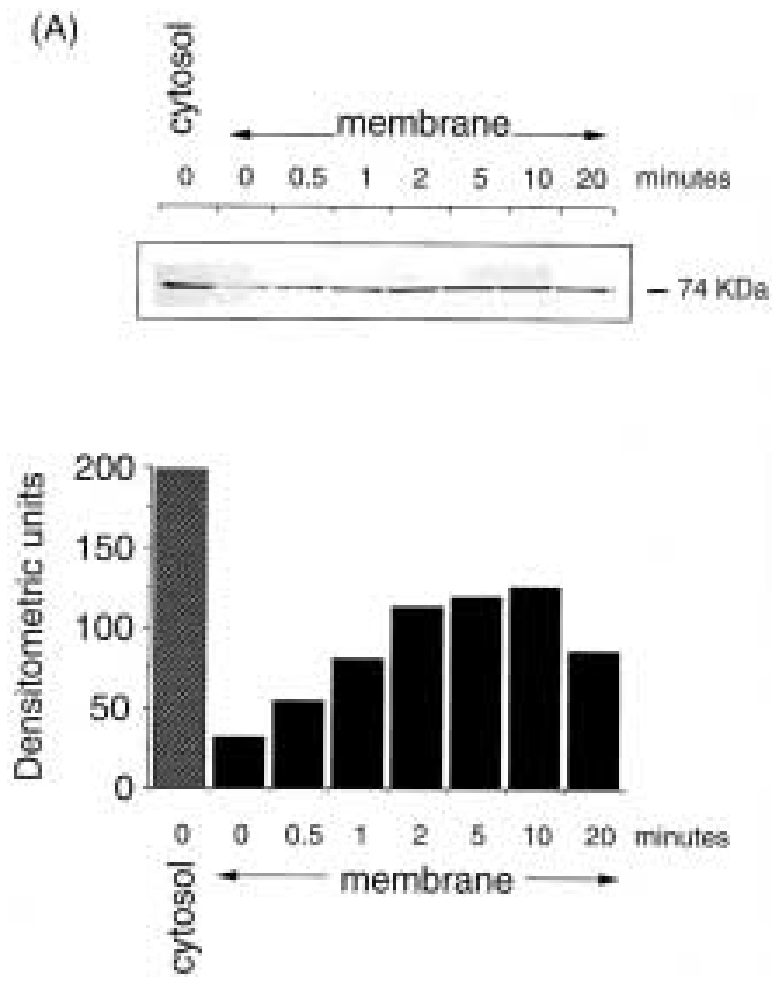

Fig. 6. Translocation of PKCı induced by PAF and its insensitivity to Ro $31-8220$ treatment. HEC-1B cells were incubated in the absence of serum for $24 \mathrm{hr}$ prior to stimulation with $1 \mathrm{nM}$ PAF either alone (A) or in the presence of the PKC inhibitor, Ro 31-8220 (B) for the times indicated. Cells incubated with PAF in the presence of $10 \mu \mathrm{M}$ Ro 31-8220 were pretreated for $30 \mathrm{~min}$ prior to stimulation. Cytosolic and particulate fractions

the identification of this isoform in the human uterus (12). The HEC-1B cells were also shown to express mRNA for inducible NOS, as is the case with human bronchial epithelial cells (25). The observed PAF-evoked NOS activation is, however, unlikely to be due to inducible NOS induction, not only because of the rapidity and magnitude of the response, but also with respect to its $\mathrm{Ca}^{2+}$-dependence. Moreover, attenuation of this effect by the PAF receptor antagonist, observed following addition of $10 \mu \mathrm{M}$ WEB2 170 after 15 min stimulation of cells with $1 \mathrm{nM}$ PAF, suggests that PAFevoked NO release is sustained rather than transient, despite peaking within $10 \mathrm{~min}$ of stimulation and then plateauing. This finding is in contrast to that observed with other $\mathrm{Ca}^{2+}$-mobilizing agonists, such as bradykinin, where the response was transient $(26,27)$.
(B)
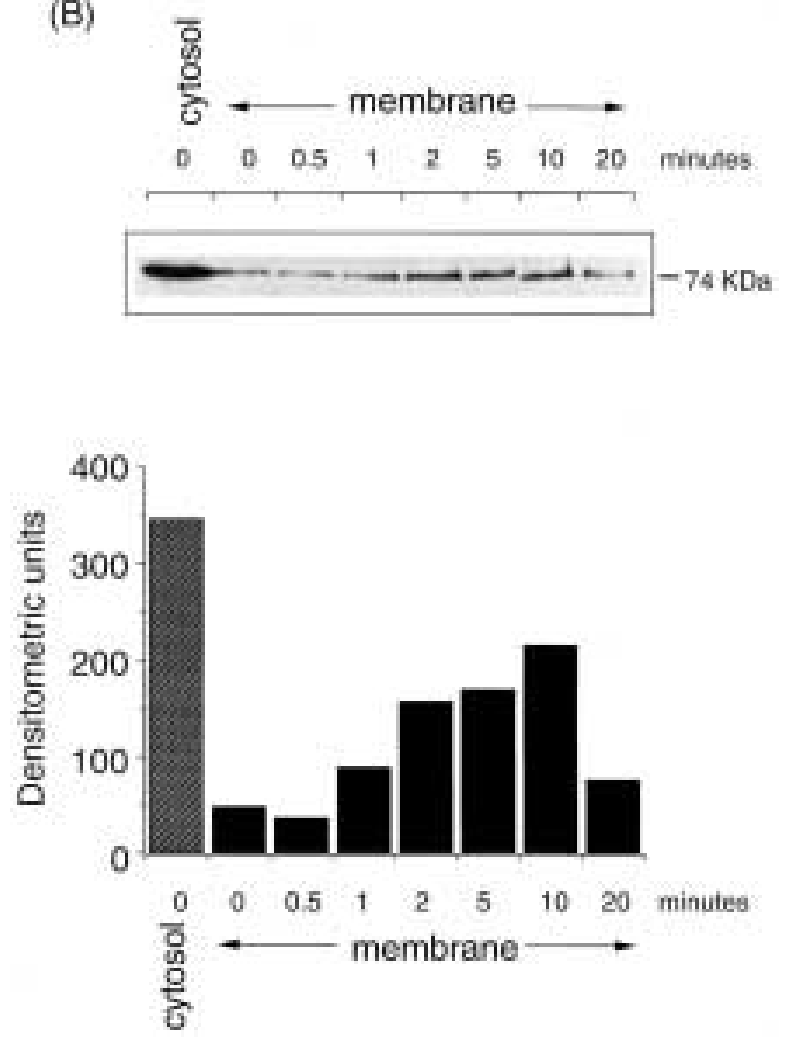

were prepared and analyzed by Western immunoblot analysis with $\mathrm{PKC} \iota$ antibody. Top panel: Western blot showing location of the iota isozyme in resting confluent cells, its association with the membrane following PAF addition (A) and failure of Ro 31-8220 to inhibit this association (B). Bottom panels of (A) and (B): Corresponding densitometric analysis. Presented are the results of a typical experiment $(n=4)$.

PAF-mediated NO release appears to be biphasic, 1 nM-PAF evokes maximal NO release while a further significant release of NO, of smaller magnitude, is evoked by $1 \mu \mathrm{M} \mathrm{PAF}$, a result which may reflect the involvement of both high and low affinity receptors in NO generation. The presence of a heterogeneous population of PAF receptors in HEC-1B cells is consistent with the identification of two distinct PAF isoreceptors in a second human adenomacarcinoma cell line derived from uterine epithelium, HEC-1A (28). PAF receptor binding studies in a number of tissues have shown the presence of high and low affinity receptor sites $(28,29)$. Autoradiography studies have indicated binding sites for PAF in the rabbit endometrium (30) and RT-PCR revealed the expression of PAF receptor mRNA in the HEC-1B cell line (16) and in situ hybridization demon- 

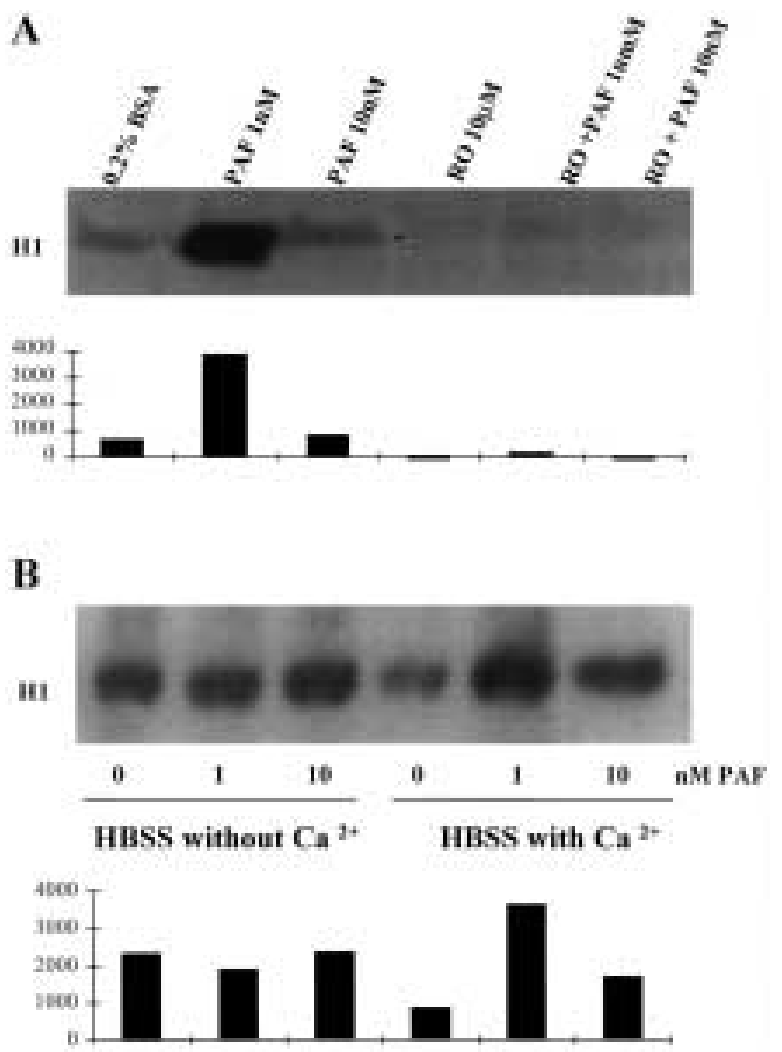

Fig 7. PAF-induced kinase activity of PKC $\alpha$ and inhibitory effect of Ro31-8220 and low $\mathrm{Ca}^{2+}$ in HEC-1B cell. (A) shows the effect of Ro 31-8220 on PAF mediated kinase activity in immunoprecipitates of PKC $\alpha$. In some experiments, cells were pretreated for 30 min with $10 \mu \mathrm{M}$ Ro31-8220 and challenged for $1 \mathrm{hr}$ with $1 \mathrm{nM}$ or $10 \mathrm{nM}$ PAF. Lysates of cells were immunoprecipitated with PKC $\alpha$ antisera and kinase reactions performed with histome $\mathrm{Hl}(\mathrm{Hl})$ as decribed in the methods section. (B) shows the effect of removing $\mathrm{Ca}^{2+}$ from the medium on PAF stimulation of PKC $\alpha$ activity. Cells were incubated in Hank's balanced salt solution (HBSS) with and without $\mathrm{Ca}^{2+}$ and challenged with 1 and $10 \mathrm{nM}$ PAF. The kinase activity in PKC $\alpha$ immunoprecipitates is shown in the graph.

strated the localization of PAF receptor mRNA in endometrial glands $(2,31)$. Our studies clearly show a biphasic response with PAF on NO release, thereby, suggesting the existence of receptor subtypes.

In HEC-1B cells, PAF activates phospholipase $C$ to yield $s n-1,2$ diacylglycerol and inositol $(1,4,5)$ trisphosphate $(16)$. Inositol $(1,4,5)$ trisphosphate induces an elevation of intracellular $\mathrm{Ca}^{2+},\left[\mathrm{Ca}^{2+}\right]_{i}$, required for $\mathrm{Ca}^{2+}$-dependent processes (31). Elevated $\left[\mathrm{Ca}^{2+}\right]_{\mathrm{i}}$ increases the activity of phospholipases. PAF also evokes a concentration-dependent rise in $\left[\mathrm{Ca}^{2+}\right]_{i}$ in HEC-1B cells, an effect which is inhibited by
WEB 2086, suggesting that it is mediated by a specific PAF receptor (16). The observation that PAF-mediated NO release is attenuated by the removal of $\mathrm{Ca}^{2+}$ from the external environment suggests dependency on extracellular $\mathrm{Ca}^{2+}$. However, since the response was not completely abolished in its absence, this suggests dependency not only on extracellular $\mathrm{Ca}^{2+}$, but also that released from intracellular stores.

Protein kinase C inhibitor Ro 31-8220attenuated NO production in response to PAF suggests that PKC may modulate the release of NO from HEC-1B cells. Ro 31-8220 has been shown to inhibit members of the conventional PKC family (PKC $\alpha, \beta$ and $\gamma$ ), which are $\mathrm{Ca}^{2+}$ and phospholipid-dependent (33). Ro 31-8220 appears to have selectivity for PKC $\alpha$ over $\mathrm{PKC} \beta, \mathrm{PKC} \gamma$ and PKC $\epsilon$ (33), the latter a representative of the $\mathrm{Ca}^{2+}$-independent PKC family. The inhibitory effect of Ro 31-8220 and the $\mathrm{Ca}^{2+}$-dependence suggests a role for a member of the conventional PKC family in the regulation of PAF-mediated NO release. The absence of isozyme-specific PKC inhibitors, however, makes it difficult to determine the involvement of specific isozymes. Consideration must also be given not only to the possible selectivity of the inhibitors for certain PKC isozymes, but also to the potential non-kinase effects of such agents at high concentrations. We, therefore, performed functional analysis of PKC activity, as well as determined the expression of PKC isozymes in HEC-1B cells.

Western immunoblot analysis revealed that the HEC-1B cell line expresses isozymes representative of all three PKC subfamilies. Major isozymes were identified as PKC $\alpha, \beta \mathrm{II}, \epsilon$ and $\iota$, the two former isozymes representing members of the conventional or calcium-dependent PKC family, and the two latter members of the novel or calcium-independent and atypical PKC families, respectively. PKC $\beta \mathrm{I}, \delta$ and $\eta$, the former a member of the conventional PKC family, and the latter two members of the novel or calcium-independent PKC family were also weakly positive on immunoblots. $\mathrm{PKC} \zeta$, a member of the atypical PKC family, was not present in detectable amounts. The isozyme profile in HEC-1B cell line was similar to that observed in normal human endometrium (2). Investigations into the isozymes translocated in response to PAF stimulation, within the time frame of NO production, revealed that both PKC $\alpha$ and PKC $\iota$ are translocated from the cytosol to the membrane upon PAF stimula- 
tion. The translocation of PKC $\alpha$ from the cytosol to the membrane in response to PAF is consistent with that observed in human endothelial cells (34). Liu et al. (35), using Chinese hamster ovary cells stably expressing wild type guinea pig PAF receptor, also found translocation of PKC $\alpha$ to the membrane following PAF stimulation. PKC $\iota$ is unlikely to be involved since translocation of the $\iota$ isozyme upon PAF stimulation was unaffected by the PKC inhibitor, Ro 31-8220. Although there are no data showing that $\mathrm{PKC} \iota$ is sensitive to Ro31-8220, indicating that the involvement of $\mathrm{PKC} \iota$ in PAF-mediated NO release can not be ruled out, it is clear from the almost complete inhibition of PAF-evoked NO release by Ro 318220 that this effect is mediate by $\mathrm{PKC} \alpha$. Kinase assays showed that $\mathrm{PKC} \alpha$ activity was stimulated following $1 \mathrm{hr}$ challenge with $1 \mathrm{nM}$ PAF and that this activation was inhibited by Ro 31-8220 and was $\mathrm{Ca}^{2+}$ sensitive. Furthermore, as for NO synthesis, higher concentrations of PAF (10 $\mathrm{nM})$ resulted in the return of PKC $\alpha$ activity to control levels. The principal PKC isozyme implicated in PAF-mediated NO release is $\mathrm{PKC} \alpha$ in HEC-1B cells.

A previous study showed that PKC activation and eNOS phosphorylation resulted in inhibition of NO production from bovine aortic endothelial cells (18). In contrast, our study demonstrates that PKC activation leads to NO production in cells of epithelial origin. Similarly, a recent study by Garcia-Cardena et al. (36) showed that heat shock protein 90 (Hsp90) rapidly associates with eNOS on growth factor stimulation, resulting in NO production. Hsp90 is postulated to act as a scaffold to allow interaction of eNOS with other regulatory proteins. We have not determined whether eNOS is a substrate of PKC $\alpha$ in HEC1B cells or whether Hsp90 forms a complex, but our data illustrate the diversity in response to PAF in different cell types.

PAF-induced vasodilatation in the rabbit afferent arteriole is highly dependent upon intact endothelium-derived NO synthesis (3). Recent reports suggest that the endotheliumdependent vasodilator effects of PAF are primarily mediated by endothelium-derived NO (37) and that NO contributes to the PAF-induced hypo-responsiveness to noradrenaline with no major role for cyclo-oxygenase products in this process (38). The ability of the endometrium to respond to PAF appears to be a feature of the preparation of this tissue for im- plantation in women $(15,31)$. The restricted PAF receptor expression pattern obtained in establishing transgenic mice suggests that the ubiquitous hyper-expression of the PAF receptor is embrionically lethal to mice (39). Furthermore, the role of PAF receptor in reproduction is indicated by the impairment of fertility in the transgenic female, which is affected by the transgene to a greater extent then the transgenic male (39). Moreover, it was previously demonstrated that failure in the regulation of PAF metabolism led to premature delivery and infertility $(40,41)$. It is also interesting to note that mice deficient of the cytosolic phospholipase $A_{2}$, the enzyme involved in the synthesis of PAF, prostaglandins and leukotrienes, displayed a reduction in fertility (42). However, PAF-receptor deficiency did not cause abnormalities in mice fertility (43), suggesting that other mechanisms of compensation are able to overcome the lack of this receptor. Alternatively, although there is no evidence for structural isoforms of the canonical PAF receptor from mRNA analysis, pharmacological studies in a variety of cell types suggest the existence of different PAF receptor subtypes (44). This study demonstrates that vasodilatation actions of PAF are likely to be due to NO release via PKC $\alpha$ and proposes that NO might both augment the vasodilatory effects of PAF in the preparation of a receptive endometrium for implantation and play a role in the regulation of menstruation.

\section{Acknowledgment}

This work was supported by grants from the Medical Research (Grant no. G9415051 and G9602 173) British Heart Foundation (Grant no PG96144) to AA. The authors also appreciate Dr. C. H. Weber, Boehringer Ingelheim Limited (Bracknell, Berkshire U.K.) for the generous gift of WEB 2170.

\section{References}

1. Ahmed A, Smith SK. (1992) The endometrium: prostaglandins and intracellular signalling at implantation. Balliere's Clinical Obstet. Gynaecol. 6: $731-754$.

2. Ahmed A, Dearn S. (1997) The role of plateletactivating factor and its receptor in endometrial receptivity. In: Nigam S (ed.) Platelet-activating Factor and Related Lipid Mediators in Health 
and Disease. Plenum Press, New York, pp. 277290.

3. Juncos L.A, Ren Y, Arima S, Ito S. (1993) Vasodilator and constrictor actions of plateletactivating factor in the isolated microperfused afferent arteriole of the rabbit kidney. Role of endothelium-derived relaxing factor/NO and cyclooxygenase products. J. Clin. Invest. 91: 13741379.

4. Palmer RMJ, Ferrige AG, Moncada S. (1989) Nitric oxide release accounts for the biological activity of endothelium-derived relaxing factor. Nature 327: 524-526.

5. Filep JG, Foldes-Filep E, Sirois P. (1993) Nitric oxide modulates vascular permeability in the rat coronary circulation. Br. J. Pharmacol. 108: 323-326.

6. McRae AC, Heap RB. (1988) Uterine vascular permeability blood flow and extracellular fluid space during implantation in rats. J. Reprod. Fertil. 82: 617-625.

7. Lowenstein CJ, Snyder SH. (1992) Nitric oxide, a novel biological messenger. Cell 70: 705-707.

8. Bredt DS, Hwang PM, Glatt CE, Lowenstein C, Reed RR, Snyder SH. (1991) Cloned and expressed nitric oxide synthase structurally resembles cytochrome P-450 reductase. Nature 351: 714-718.

9. Marsden PA, Schappert KT, Chen HS, Flowers, M, Sundell CL, Wilcox JN, Lamas S. et al. (1992) Molecular cloning and characterization of the constitutive bovine aortic endothelial cell nitric oxide synthase. J. Clin. Invest. 90: 2092-2096.

10. Xie QW, Cho HJ, Calaycay J, Mumford RA, Swiderek KM, Lee TD, Ding A, et al. (1992) Cloning and characterization of nitric oxide synthase from mouse macrophages. Science 256: 225-228.

11. Knowles RG, Moncada S. (1992) Nitric oxide as a signal in blood vessels. Trend. Biochem. Sci. 17: 399-402.

12. Telfer J.F, Lyall F, Norman JE, Cameron IT. (1995) Identification of nitric oxide synthase in human uterus. Hum. Reprod. 10: 19-23.

13. Chaudhuri G., Nathan L. (1992) Nitric oxide and endometrial blood flow. In: Steroid Hormones and Uterine Bleeding. Alexander NJ, d'Arcangues C, (eds.) AAAS Publication, Washington, DC, pp. 241-244

14. Shams M, Sisi P, Ahmed A. (1996) Localisation of bradykinin type II receptor mRNA in human endometrium. Mol. Human Reprod. 2: 35-39.

15. Ahmed A, Smith SK. (1992) Platelet activating factor stimulates phospholipase $\mathrm{C}$ activity in human endometrium. J. Cell Physiol. 152: 207-214.

16. Ahmed A, Sage SO, Plevin R, Shoaibi M.A, Sharkey AM, Smith SK. (1994) Functional platelet-activating factor receptors linked to inositol lipid hydrolysis, calcium mobilization and tyrosine kinase activity in the human en- dometrial HEC-1B cell line. J. Reprod. Fertil. 101: 459-466.

17. Bredt DS, Ferris CD, Snyder SH. (1992) Nitric oxide synthase regulatory sites. J. Biol. Chem. 267: 10976-10981.

18. Hirata K, Kuroda R, Sakoda T, Katayama M, Inoue N, Suematsu M, Kawashima S, et al. (1995) Inhibition of endothelial nitric oxide synthase activity by protein kinase C. Hypertension 25: 180-185.

19. Clemens MJ, Trayner I, Menaya J. (1992) The role of PKC isoenzymes in the regulation of cell proliferation and differentiation. J. Cell Sci. 103: 881-887.

20. Dorit R, Kazanietz MG. (1999) New Insights into the regulation of protein kinase $\mathrm{C}$ and novel ester receptors. FASEB $J$ 13: 1658-1676.

21. Chomczynski P, Sacchi N. (1987) Single-step method of RNA isolation by acid guanidinium thiocyanate phenol chloroform extraction. Analytical Biochem. 162: 156-159.

22. Ahmed A, Dunk C, Kniss D, Wilkes M. (1997) Role of VEGF receptor (Flt-1) in mediating calcium-dependent nitric oxide release and limiting DNA synthesis in human trophoblast cells. Lab. Invest. 76: 779-791.

23. Monks CRF, Kupfer H., Tamir I, Barlow A, Kupfer A. (1997) Selective modulation of PKC- $\theta$ during T-cell activation. Nature 385: 83-86.

24. Lowenstein CJ, Dinerman JL, Snyder SH. (1994) Nitric oxide: a physiologic messenger. Ann Int. Med. 120: 227-233.

25. Asano K, Chee CBE, Gaston B, Lilly CM, Gerard C, Drazen JM, and Stamler JS. (1994) Constitutive and inducible nitric oxide synthase gene expression, regulation and activity in human lung epithelial cells. Proc. Natl. Acad. Sci. U.S.A. 91: 10089-10093.

26. Buckley BJ, Mirza Z, Whorton AR. (1995) Regulation of $\mathrm{Ca}^{2+}$-dependent nitric oxide synthase in bovine aortic endothelial cells. Am. J. Physiol. 38: C757-C765.

27. Blatter IA, Taha Z, Mesaros S, Shacklock PS, Wier WG, Malinski T. (1995) Simultaneous Measurements of $\mathrm{Ca}^{2+}$ and Nitric Oxide in Bradykinin-stimulated vascular endothelial cells. Circulation Res. 76: 922-924.

28. Baldi E, Bonaccorsi L, Finetti G, Luconi M, Murator M, Susini T, Forti G, et al. (1994) Plateletactivating factor in human endometrium. J. Steroid. Biochem. Mol. Biol. 49: 359-63.

29. Kudolo GB, Harper MJK. (1989) Characterization of platelet-activating factor binding sites on uterine membranes from pregnant rabbits. Biol. Reprod. 41: 587-607.

30. Kudolo GB, Kasamo M., Harper MJK. (1991) Autoradiographic localization of plateletactivating factor (PAF) binding sites in the rabbit endometrium during the peri-implantation period. Cell Tissue. Res. 265: 231-241. 
31. Ahmed A, Dearn S, Sangha R, Li XF, Shams M, Rola-Pleszczynski M, Jiang J. (1998) Localization, quantification and activation of plateletactivating factor receptor in human endometrium during the menstrual cycle: PAF stimulates NO, VEGF and FAKpp125. FASEB J. 12: 671-683.

32. Barzaghi GH, Sarau M, Mong S. (1989) Plateletactivating factor-induced phosphoinositide metabolism in differentiated U-937 cells in culture. J. Pharmacol. Exp. Therap. 248: 559-566.

33. Wilkinson SE, Parker PJ, Nixon JS. (1993) Isoenzyme specificity of bisindolylmaleimides, selective inhibitors of protein kinase C. Biochem. J. 294: 335-337.

34. Bussolino F, Silvagno F, Garbarino G, Costamagna C, Sanavio F, Arese M, Soldi R, et al. (1994) Human endothelial cells are targets for platelet-activating factor (PAF): activation of alpha and beta protein kinase C isozymes in endothelial cells. J. Biol. Chem. 269: 2877-2886.

35. Lui B, Nakashima S, Takano T, Shimizu T, Nozawa Y. (1995) Implication of protein kinase C $\alpha$ in phospholipase activation in Chinese hamster ovary cells expressing PAF receptor. Biochem. Biophys. Res. Commun. 214: 418-423

36. Garcia-Cardena G, Fan R, Shah V, Sorrentino R, Cirino G, Papapetropoulos A, Sessa WC. (1998) Dynamic activation of endothelial nitric oxide synthase by Hsp 90. Nature 392: 82 1-824.

37. Kamata K, Numazawa T, Kasuya Y. (1996) Characteristics of vasodilatation induced by acetylcholine and platelet-activating factor in the rat mesenteric arterial bed. Eur. J. Pharmacol. 298: 129-36.

38. Shiga T, Yoshikawa D. (1995) Platelet-activating factor-induced loss of vascular responsiveness to noradrenaline in pithed rats: involvement of nitric oxide. Eur. J. Pharmacol. 282: 151-156.

39. Ishii S, Nagase $T$, Tashiro F, Ikuta K, Sato S, Waga I, Kume, K, et al. (1997) Bronchial hyperreactivity, increased endotoxin lethality and melanocytic tumorigenesis in transgenic mice overexpressing platelet-activating factor receptor. ЕМВO J. 16: 133-142

40. Narahara H, Tanaka Y, Kawano Y, Gholbzouri K, Miyakawa I, Johnston JM. (1995) Platelet-activating factor-acetylhydrolase activity in follicular fluid of patients undergoing in vitro fertilization and embryo transfer. Fertil. Steril. 64: 1172-1176.

41. Toyoshima K, Narahara H, Furukawa M, Frenkel RA, Johnston JM. (1995) Plateletactivating factor. Role in fetal lung development and relationship to normal and premature labor. Clin. Perinatol. 22: 263-280

42. Bonventre JV, Huang Z, Taheri MR, O'Leary E, Li E, Moskowitz MA, Sapirstein A. (1997) Reduced fertility and postischaemic brain injury in mice deficient in cytosolic phospholipase A2. Nature 390: 622-625

43. Ishii S, Kuwaki T, Nagase T, Maki K, Tashiro F, Sunaga S, Cao W-H, et al. (1998) Impaired anaphylactic responses with intact sensitivity to endotoxin in mice lacking a platelet-activating factor receptor. J. Exp. Med. 187: 1779-1788.

44. Chen J, Giri SN. (1997) Differences in plateletactivating factor receptor mediated $\mathrm{Ca}^{++}$response between hamster and guinea pig alveolar macrophages. J. Pharmacol. Exp. Ther. 281: 1047-1058. 